\title{
Versification: Metrics in practice, 25th-27th May 2016, Helsinki, Finland
}

\section{Satu Grünthal, Erika Laamanen}

The international and multidisciplinary conference Versification: Metrics in Practice was held in Helsinki, Finland from $25^{\text {th }}$ to $27^{\text {th }}$ May 2016. The conference was a meeting of NordMetrik (Nordic Society for Metrical Studies). Scholars from a variety of disciplines and from fifteen different countries gathered in the Great Hall of the Finnish Literature Society and the Topelia building of the University of Helsinki to discuss questions of metrics. The conference was organized by the Department of Folklore Studies and the Department of Finnish, Finno-Ugrian and Scandinavian Studies at the University of Helsinki, the Academy of Finland project "Oral Poetry, Mythic Knowledge and Vernacular Imagination", and the Finnish Literature Society.

The theme of the conference was 'metrics in practice.' Versification describes the marriage of language and metre: it is the key to the production of poetry. This phenomenon attracts researchers from a wide variety of intersecting disciplines, ranging from metricists proper and researchers of cognitive poetics to scholars of folklore, linguistics, linguistic anthropology, literature, musicology, philology and more. The aim of the conference was to highlight the inseparability of metre and language and to call attention to metre in different social language practices.

The five keynote speakers of the conference approached the theme from different angles. Tomas Riad (Stockholm University, Swedish Academy) argued against the idea that metre is an abstract pattern filled with language - the idea supported by, for example, generative metrics. Instead, he suggested that in the case of metre we are dealing with the same kind of phenomenon as prosodic morphemes and that metre should therefore be treated at root as a linguistic object. The central idea of his lecture was metre as improvement. According to Riad, improvement occurs when metred discourse obeys one or more linguistic constraints or conventions more regularly than other forms of language use.

Paul Kiparsky (Stanford University), a pioneer of generative metrics, considered interrelations between a metre and the language in which it is used. He spoke about how metres, in addition to historical context, adjust to functional preferences. For example, genre is a factor affecting the choice of metre. Epic and dramatic forms use flexible metres that have a simple underlying pattern but complex correspondence constraints, the combination of which offers a 
variety of realization options. Sung lyric poems, on the other hand, consists of a wide range of complex metrical structures with simple correspondence constraints. In each case, the correspondence constraints and the types of flexibility that they evolve have dependencies on the language of performance.

Poet and philologist Jesper Svenbro (Swedish Academy) provided a practitioner's perspective on Sapphic and Alcaic stanzas, linking his philological research on these poetic forms to the reflective analysis of his own uses of them and resultant choices in the composition process. In addition to his own poetry, he presented examples from Sappho, Friedrich Hölderlin and Tomas Tranströmer proving the vitality of Sapphic and Alcaic stanzas in modern poetry.

Kati Kallio (Finnish Literature Society) discussed the relationship between metre, music and performance in oral poetry. Kallio began by stating that with oral poetry it is problematic to consider metre exclusively as an abstract pattern. Illustrated with many examples, she presented ways in which Finnic language-speaking peoples have sung poetry and varied metre according to a given performance situation.

Jarkko Niemi (University of Tampere) gave a lecture based on his research project involving the musical traditions, and especially sung expression, of the indigenous ethnic groups living in western Siberia and northwestern Russia, looking especially at peoples speaking Samoyedic and Ob-Ugrian languages. He highlighted that the linguistic structure of a metrical line could be significantly, if regularly, altered and reorganized as an organic part of oral performance. In his lecture, Niemi presented the results of his project that also cast light on the local cultures more broadly, revealing that areal patterns in the singing traditions of these different groups had evolved through their contact history.

A wide variety of verse forms, traditions and languages were examined during presentations in the parallel sessions, ranging from poetry of Antiquity to recent folklore and from medieval court poetry to rap music of the $21^{\text {st }}$ century. Many of the presentations dealt with metre in sung poetry and music, and classical music and translation studies were also included in the program. Approaches and methods of the presentations varied as well.

During the conference, poetic traditions were discussed e.g. by Haukur Porgeirsson (Árni Magnússon Institute for Icelandic Studies) and Frog (University of Helsinki). In his presentation, Haukur Porgeirsson proposed the idea of two different types of poetic traditions, splitting and lumping ones. Splitting traditions require the poets to make distinctions not found in their contemporary language. Lumping traditions, on the other hand, allow poets to ignore some of the distinctions found in the language for the purposes of 
rhyme or other poetic effects. - In his talk, Frog introduced the concept of metrical entanglement. In contrast to metrical motivation, which describes a purely formal relationship between metre and language without reference to conventions of social practice, metrical entanglement describes links that develop socially between language and metre.

Maria-Kristiina Lotman (University of Tartu) and Mihhail Lotman (University of Tartu / Tallinn University) introduced their new research project in which they study the relationship between metre and semantics by means of statistical-comparative analysis. In addition to comparing two different periods also the lexis of various verse metres has been analysed, especially that of the main metres of the earlier poetry, i.e. iambic and trochaic tetrameters, while comparative material has been provided by hexameter. The lexical analysis has revealed differences between verse traditions as well as verse metres in every analysed aspect.

Issues of textsetting were discussed in the presentations of Lev Blumenfeld (Carleton University) and Nicolas Royer-Artuso (Laval University). Lev Blumenfeld argued on the basis of data from Georges Brassens that textsetting constraints, while related to metrical ones, form a distinct system, and that textsetting interfaces with phonology directly. Nicolas Royer-Artuso discussed how Ottoman court poetry was driven structurally by the demands of the borrowed Arabic metre system, Aruz, and proposed some general textsetting principles.

Nordic metres were discussed in several presentations. Klaus Johan Myrvoll (University of Oslo), for example, talked about syllabic quantity in old Norse metre, and Yelena Sesselja Helgadóttir (University of Iceland) analysed formulaic language in postmedieval Icelandic pulur, which are on the borderline between verse and prose. Questions of Faroese poetry, both old and contemporary, were discussed in two presentations: Daniel Galbraith (Stanford University) presented a constraint-based account of Faroese ballad metre, and the rhymes and rhythms in a modern bricolage of hip hop, romantic poetry and ballads ("Frá bygd til bý" by Swangah Dangah) was discussed by Dragana Cvetanovic, Satu Grünthal and Martina Huhtamäki (University of Helsinki).

Estonian folk poetry was the topic in the presentations of Taive Särg (Estonian Folklore Archives, Tartu), Mari Sarv (Estonian Literary Museum), and Janika Oras (Estonian Literary Museum). Taive Särg talked about the regilaul metre, which is both a mental model that organises singing, and a set of formal features, being (re)created while singing. She asked what makes singers to perform differently the long verses of very similar or even of the same rhythmic structure. Mari Sarv discussed the relationship of metre and performance in folksongs, where metrical and musical templates are not totally 
independent, but structure one another mutually. Janika Oras concentrated on polyphonic Seto oral singing tradition and analysed the broken line as a model of rhythmic variation. Not all of the variations are definite and predictable, because while performing some types of verses, the singers can use alternative rhythmic solutions. So the performance resembles a (mutual) play of the singers - the lead singer and the choir - with rhythmic structure.

The topic of Eila Stepanova (University of Helsinki) were Karelian laments, which are composed in rhythmic-melodic "poetic strings" of variable length united by alliteration and melody. Russian folk laments were discussed by Elena Jugay (Russian State University).

Myfany Turpin (University of Sydney) analysed multimodal parallelism in Central Australian song-poetry. Awelye, a performance of traditional Aboriginal song-poetry, is characterized by parallelism of form and meaning in the textual, musical and visual modalities of this multimodal performance genre. Maria V. Stanyukovich (Peter the Great Museum of Anthropology and Ethnography (Kunstkamera), Russian Academy of Science), discussed the correlation of text and melody in a hudhud-shaped dirge of the Yattuka, an indigenous and highly endangered group of Philippine highlanders.

Central and Southern European traditions were brought up by Jean-Louis Aroui (Paris-8 University) through the French decasyllable from the 14th to the 16th Century, and by Rosalía Rodríguez-Vázquez (University of Vigo), through Galician song metrics in the Iberian phonological continuum. Hans Nollet (KU Leuven) discussed the dactylic hexameter in the poetry of the Brabant humanist Justus Lipsius (1547-1606).

Russian topics were discussed e.g. by Marina Akimova (Lomonosov Moscow State University) and Vera Polilova (Lomonosov Moscow State University). Marina Akimova made observations on the use of verb forms in the poetry of Mikhail Kuzmin, and Vera Polilova presented a talk about the genesis of the Russian taktovik and identified it as an independent metre in the system of Russian tonic versification.

Eva Lilja (Göteborg University) spoke on "Embodied Rhythm". Employing the example of Ann Sexton's poem "The Fury of Rain Storms" she explicated how rhythm produces meaning by using a four step analysis model. Varun de Castro-Arrazola (Leiden University / Meertens Institute) presented a study about the source of final strictness in verse lines. These data were compared to corpus analyses of verse in several languages, and a model of attention was proposed as the cognitive factor driving both types of data.

Finnish issues were discussed e.g. by Hanna Karhu (University of Helsinki), who talked about Finnish rhymed couplet metre in original folk songs, in rewritings of the poet Otto Manninen, and also in his poems that resemble 
folk songs. Erika Laamanen (University of Helsinki) analysed the metrical evolution of Lauri Viita's poetry, and Eeva-Liisa Bastman (University of Helsinki) spoke on Finnish 18th Century Hymn Poetry in the light of rhyme, assonance and alliteration. The aim of her paper was to explore the functions and uses of different forms of sound repetition for the stanza structure and for the hymn as a significant whole.

The lively and fruitful discussions that followed each presentation were continued in the evenings. The first evening of the Conference was spent on Tervasaari island, where the attendees had the opportunity to talk about syllables and statistics in an informal manner with good food and nice weather. On Thursday evening, Tuomas Lehtonen, the Secretary General of Finnish Literature Society, welcomed everyone to the Society-organized reception. To the great delight of all, Stephen Evans, conference participant and church musician (Parish of Laitila, Turku Archdiocese), offered a short piano performance of "Berceuse" by Armas Järnefelt and "Yö meren rannalla" ['Night by the Sea'] by Heino Kaski.

A publication about the conference is currently being organized. The next meeting of NordMetrik is already being planned and is expected to be held in Stockholm in 2018. 